\title{
THE USE OF ‘SHAME’ WITH SEXUAL OFFENDERS
}

\author{
Anne-Marie McAlinden*
}

This article explores the use of shaming mechanisms with sexual offenders, particularly those who offend against children. Shaming - a central concept in the broader theory of restorative justicemay be of two varieties. The first-'disintegrative shaming'-characterizes the traditional retributive framework of justice and is evident in recent state-led and popular responses to the risk posed by released sexual offenders. Far from ensuring offender integration, the net result is often labelling, stigmatization, ostracism and a return to offending behaviour. The second-'reintegrative shaming'affirms the offender's membership within law-abiding society. This has been used in several jurisdictions as the basis of restorative support and treatment networks for sexual offenders where the community works in partnership with state and voluntary agencies. Contrary to arguments put forward by critics of restorative justice, this article argues that such cases may be particularly suitable for a restorative approach.

\section{Introduction}

The contemporary politics of crime control places a strong emphasis on public protection, risk management and preventive governance as part of the 'new penology' (Feeley and Simon 1992), 'risk society' (Beck 1992; Ericson and Haggerty 1997) or 'the new regulatory state' (Braithwaite 2000; Shearing 2000). In recent years, there has been acute popular and governmental concern with managing those perceived to be a danger to society. As Rose (2000) argues, however, there is conflict and wide variation in the methods of social control deployed (Garland 1996; 2001; O'Malley 1999). These range from punitive demands for execution or preventive detention of dangerous or 'risky' individuals, such as paedophiles and persistent violent offenders, to the development of multi-agency work on the assessment and management of risk and the use of therapeutic and rehabilitative alternatives via community disposals and reintegrative shaming (Rose 2000: 321). The current focus of criminal justice policy, therefore, is seemingly on a 'what works' approach, which may help to explain the wide variation of measures used. When it comes to sexual offences, however, particularly those against children, the salient point is that the traditional retributive form of state justice does not seem to be working. ${ }^{2}$

Indeed, child sexual abuse is a small component of the broader category of 'gendered and sexualised violence' (Hudson 2002), including domestic violence, which causes significant trauma for victims (Herman 1997) yet continues to evade conventional

\footnotetext{
* Institute of Criminology and Criminal Justice, School of Law, Queen's University Belfast. The author wishes to thank a number of reviewers, some of whom are anonymous, for helpful comments on an earlier draft of the paper, in particular, Professor Harry Mika of Central Michigan University.

${ }^{1}$ Feeley and Simon alternatively use the label 'actuarial justice' in this context (1994).

${ }^{2}$ Recorded crime statistics show that the total number of recorded sexual offences has increased by $9.6 \%$ in the period $1999 /$ 2000 to 2001/2002 and by $94.4 \%$ in the last 25 years ('Recorded Crime Statistics: 1898-2001/02', http://www.homeoffice.gov.uk/ $\mathrm{rds} / \mathrm{pdfs} / 100 y e a r s . x l s)$. Moreover, recent Home Office research reveals that actual recidivism rates for sexual offenders are 5.3 times the official reconviction rate (Falshaw et al. 2003).
} 
approaches to justice. There is a need, therefore, to re-examine and perhaps redefine the current regulatory framework in respect of these offences. The failure of formal criminal justice thus far with respect to these types of offences also means that there is considerable scope for exploring alternative forms of justice and their potential for improving the outcome for victims, offenders and communities affected by sexual offences (Finstad 1990; Braithwaite and Daly 1994).

In this vein, some criminologists continue to emphasize the difference of the restorative justice vision as a paradigm shift in criminal law (Zehr 1990; 1995; Bazemore 1996; Barnett 2003; Walgrave 2003). Others, however, call for recognition of alternative forms of justice and highlight the compatibility of restoration and retribution. These two concepts may in fact be integrated as part of the same system of justice, where they would complement and work in tandem with each other rather than operate as opposing or alternative systems (Zedner 1994; Levrant et al. 1999; Daly 2000; Duff 2002; Hudson 2002)..$^{3}$

Following Braithwaite's (1989) dichotomy of reintegrative and disintegrative shaming, this article will argue that within the retributive framework, previous legislative and judicial attempts to control sex offenders in the community upon release from custody are largely disintegrative in nature. These include measures such as sex offender registration and community notification and novel probation conditions imposed in the United States. The media have followed suit with the adoption of 'name and shame' campaigns, which encourage public outcry and often vigilante justice. Far from securing the offender's rehabilitation, this negative labelling of offenders may serve to heighten their isolation from the law-abiding community and may ultimately lead to a return to offending behaviour (Maxwell and Morris 1999). ${ }^{4}$

On the other hand, some sporadic and isolated efforts have been made in jurisdictions such as Canada and parts of the United States which have effected significant benefits in 'reintegrative shaming' with sex offenders. There are considerable variations in approach but, at a broad level, these programmes involve the development of networks of support and treatment, involving the offender, the wider community and state or voluntary agencies. It will be argued that criminal justice policy and practice need to recognize the potential of restorative programmes in this context and adopt these on a wider and more holistic basis.

The structure of the article will be as follows: Part I will provide the theoretical framework by outlining the prominent features of restorative justice and of shaming practices in particular. Part II will outline examples of disintegrative shaming practices with sex offenders which exist in United Kingdom and the United States. Part III will consider examples of innovative reintegrative shaming practices with sex offenders in Canada and parts of the United States and explore how these could usefully be employed in the United Kingdom. Finally, Part IV will address some of the key concerns put forward by critics of restorative justice as applied to sexual offences and those surrounding the implementation of shaming mechanisms in particular. It will further argue that victims, offenders, families and the wider community affected by child sexual abuse could gain significant benefits from the widespread adoption of such an approach.

\footnotetext{
${ }^{3}$ Some restorative-justice commentators, however, have argued that, in fact, restorative-justice systems are corroded by their partnership with a retributive framework (Boyes-Watson 1999).

${ }^{4} \mathrm{~A}$ middle position, of course, is that behaviour is unaffected.
} 
THE USE OF 'SHAME' WITH SEXUAL OFFENDERS

\section{Part I: The Theoretical Framework}

\section{Restorative justice}

In modern thinking about restorative justice, such approaches routinely comprise the three central actors of the victim, the offender and the community (Zehr 1990). As a concept, however, it is not easy to define. One recent and much used definition was proffered by Marshall as 'a process whereby all the parties with a stake in a particular offence come together to resolve collectively how to deal with the aftermath of the offence and its implications for the future' (Marshall 1999: 5).$^{5}$ Essentially, it focuses on 'changing the normative orientation of law from retribution to restoration' (Hudson 1998: 238). It views crime not as a violation of a general legal category but as harm to individual people and relationships and, as the term suggests, seeks to redress or restore that harm (Consedine 1995; Van Ness and Strong 1997).

The term 'restorative justice' has been used to cover a variety of practices that seek to respond to crime in what is seen to be a more constructive way than through the use of conventional criminal-justice approaches. The main variants include victim-offender mediation in the United States, United Kingdom, Germany and Austria (Marshall 1991; Davis 1992; Umbreit 1994), family-group conferencing in New Zealand and Australia (McElrea 1994; Retzinger and Scheff 1996; Morris and Maxwell 2000) and circles of support and accountability in Canada (Cesaroni 2001; Petrunik 2002; Wilson et al. 2002). ${ }^{6}$ The latter is of particular relevance to reintegrative efforts with sex offenders and will be discussed further below.

Restorative-justice approaches in various jurisdictions may differ but are often based on the following common aims: engaging with offenders to help them to appreciate the consequences of their actions and the impact that they have had on their victims; encouraging appropriate forms of reparation by offenders towards their victim, if they agree, or the wider community; seeking reconciliation between the victim and offender, where possible, and the reintegration of the offender within the community. It is these broad aims which are evidenced in reintegrative shaming efforts with sexual offenders and which will be discussed further below.

\section{Shaming}

The concept of restorative justice owes much to Braithwaite's notion of 'reintegrative shaming' (Braithwaite 1989; Ahmed et al. 2001). ${ }^{7}$ Braithwaite defines shaming as 'all

\footnotetext{
${ }^{5}$ Braithwaite (1999: 5) endorses this definition. However, as Zehr and Mika note, as restorative programmes become more widespread, the number of definitions has increased significantly (1998: 47). The latter provide a fundamental definition based on a 'values approach', which comprises three major themes: (1) crime as a violation of persons, interpersonal relationships and community that (2) creates harms, obligation and liabilities and (3) justice processes that address needs and seek to heal and right wrongs. These components are also endorsed as the core principles of restorative justice practice in the context of paramilitary punishment violence in Northern Ireland (Mika and McEvoy 2001).

${ }^{6}$ Within the Canadian justice system, there are both 'sentencing circles' (SC) and 'circles of support and accountability' (COSA). These terms are often used interchangeably but are in fact two separate entities. SC can be utilized at the outset of the sanctioning process, prior to an offender's becoming lodged within the system. COSA, on the other hand, focus in particular on the reintegration of high-risk sex offenders (Wilson et al. 2002).

${ }^{7}$ There is also a debate surrounding the exact parameters of the relationship between reintegrative shaming and restorative justicein particular whether the terms 'reintegration' and 'restoration' are inter-changeable or at least complementary (Walgrave and Aersten 1996). There are those who do not see shaming as an essential part of restorative justice and suggest that emotions such as empathy and remorse may be more crucial in effecting a reparative response (Maxwell and Morris 2002; 2004; van Stokkom 2002).
} 
social processes of expressing disapproval which have the intention or effect of invoking remorse in the person being shamed and/or condemnation by others who become aware of the shaming' (1989: 100). Thus, the essence of the theory is that the ways in which not only the state, but also society, the community and the family, sanction deviance affect the extent to which their members engage in predatory criminal behaviour. According to Braithwaite, however, the shame which matters most is not 'the shame of the remote judge or police officer but the shame of the people they most care about' (1993: 37).

Shaming, therefore, is not a uniform sanction but can be done in a variety of ways and contexts (Hay 2001: 133-5). Braithwaite makes the distinction between two types of society and two types of shaming practice. He argues that communitarian societies (i.e. those with a high degree of interdependence and strong cultural commitments to group loyalties) are better able than others (where there is a lower level of interdependence and greater concern for the expression of individualism) to informally sanction deviance and reintegrate lawbreakers by shaming the offence, rather than permanently stigmatizing the offender through harsh formal penal codes (Braithwaite 1989: 84-5). In this vein, he contrasts the reintegrative shaming of the good parent, who makes clear his or her disapproval of bad behaviour without rejecting the child, with the stigmatizing shame of modern criminal justice.

There are two facets to reintegrative shaming: (1) the overt disapproval of the delinquent act (shaming) by socially significant members; and (2) the on-going inclusion of the offender within an interdependent relationship (reintegration) (Zhang 1995: 251). Thus, shaming is reintegrative when it reinforces an offender's membership in civil society. This prevents the shamed individual from adopting a 'deviant master status' (Becker 1963; 1974) and is accomplished when shaming (1) maintains bonds of love or respect between the person being shamed and the person doing the shaming, (2) is directed at the evil of the act rather than the evil of the person, (3) is delivered in a context of general social approval, and (4) is terminated with gestures or ceremonies of acceptance and forgiveness (Braithwaite 1989: 100-1).

Reintegrative shaming can be contrasted with stigmatization which is disintegrative in nature. Little or no effort is made to forgive offenders or affirm the basic goodness of their character and thus reinforce their membership in the community of lawabiding citizens. Stigmatization is essentially shaming in the absence of a reintegrative element and is the converse of each of the four elements mentioned above (Garfinkel 1956). The primary relevance of stigmatization is that it shuns offenders and treats them as outcasts and may provoke a rebellious and criminal reaction from them (Karp 1998: 283; Maxwell and Morris 1999). As Vagg (1998: 254) has argued, labelling is therefore the key element that separates reintegrative from disintegrative shaming.

As the next section will demonstrate, the theory of disintegrative shaming has, for the most part, informed contemporary responses to the risk posed by released sex offenders in the community.

\section{Part II: Disintegrative Shaming Practices}

The use of disintegrative shaming mechanisms is not new. History is littered with examples of the public spectacle of punishment where shaming and public humiliation were 
used in order to exact punishment for an offence (Foucault 1977: 3-72). ${ }^{8}$ Today, faced with the reality of ineffective and overcrowded prisons, the legislature, the executive and the judiciary, particularly in the United States, have not lost sight of the potential of shame penalties for certain classes of offenders, including sex offenders. ${ }^{9}$ These unusual forms of public punishments, which are aimed at community safety and are intended to shame offenders into greater respect for the law and create a powerful deterrent to reoffending (Karp 1998), may also have a disintegrative or stigmatizing rather than a reintegrative effect. Contemporary disintegrative shaming practices can be further divided into state-led and popular responses to sex offending.

\section{State-led responses}

In recent years, in both the United States and the United Kingdom, there has been widespread media and public outcry over crimes committed by convicted sexual offenders shortly after their release from prison. In response to this 'populist punitiveness' (Bottoms 1995), governments have enacted statutes establishing registration and notification schemes with the broad aims of specific deterrence and public protection (Home Office 1996: para. 43). ${ }^{10}$ 'Megan's Law' in the United States and Part II of the Sexual Offences Act $2003^{11}$ in the United Kingdom require certain classes of sex offender to register their details with the police.

Registration of the offender's name and address and notification of this information to the community in particular may result in a social stigma being attached to the offender (Massaro 1991; Bedarf 1995: 911-13). Some commentators have argued that community notification is tantamount to putting someone in a public stock, to a brand on the forehead or, in the words of Hawthorne's novel, to 'A Scarlet Letter' ${ }^{12}$ (Earl-Hubbard 1996; Kimball 1996; Van Dujn 1999).

Mandatory self-identification is one of the forms of community notification which exists in the United States (Bedarf 1995: 903-6). In some states, released sexual offenders are required to wear a scarlet letter ' $S$ ' on the front of their clothing to signify to the rest of the community that they are a convicted sexual offender. In a few states, offenders must hand out handbills or flyers to their neighbours which contain a picture, physical description and details of their offences, or send notice in writing informing them of their past offending history. In other states still, most notably Louisiana, offenders are required to go door to door within a radius of several blocks personally informing their neighbours that they are a convicted sexual offender (Logan 1999; Petrunik 2002: 493). In addition, community notification provisions also allow law-enforcement officials to take steps to distribute the information about offenders (Van Dujn 1999: 645). These include wanted posters and databases of all known local sex offenders, which are available via the internet.

\footnotetext{
${ }^{8}$ Punishments such as flogging, hanging, drawing and quartering, the stocks and the pillory, and branding were carried out publicly and in ceremonial fashion, and were designed to inflict physical suffering in tandem with social disgrace (Ives 1914: 53; Barnes 1930: 62-3; Hibbert 1963: 28; all cited in Brilliant 1989: 1361).

9 'American Criminals Sentenced to Shame', The Sunday Times, 20 April 1997.

${ }^{10}$ See also United States Congressional Record (139 Cong. Rec. H10, 320).

${ }^{11}$ This Act replaces the registration provisions contained in Part I of the Sex Offenders Act 1997.

${ }^{12}$ In this fictional account of Seventeenth Century Boston, the plight of Hester Prynne, an adulteress forced to wear a scarlet letter 'A' embroidered on the front of her dress to show her crime, embodies what was then Puritan society's use of punishment by humiliation and shame (Hawthorne 1994).
} 
In response to the limitations of and the frustrations with the conventional options of prison and parole, a minority of judges in the United States have also begun to use shame penalties as part of modern probation conditions, particularly for sex offenders (Kahan 1996). In practice, there are several types of shaming mechanism, namely signs and apologies (Massaro 1991: 1886-90; Karp 1998: 281-3).

The sign sanctions are the most obvious illustrations of disintegrative shaming. In one case, ${ }^{13}$ the court placed a convicted child molester on probation for five years subject to a condition, among others, that he place a sign on both sides of his car and on the door of his residence in three-inch lettering which read: 'Dangerous Sex Offender-No Children Allowed' (Brilliant 1989: 1365-6; Kelley 1989: 760; Massaro 1991: 1887-8). Bateman had previously been convicted of sexually abusing a child.

The second type of shame sanction is the public apology or confession. Other courts have required sex offenders to place ads in the local newspaper, publicizing their offences or urging others to sex treatment. A Rhode Island Superior Court Judge required an offender to purchase an advertisement in the Providence Journal-Bulletin, reading: 'I am Stephen Gererhausen, I am 29 years old . . . I was convicted of child molestation ... . if you are a child molester, get professional help immediately, or you may find your picture and name in the paper and your life under the control of the state' (Massaro 1991: 1880).

The central component of these penalties is public exposure-to bring the crime to the attention of the public so that they may respond with shaming (Karp 1998: 281). Their primary purpose is not to humiliate or draw public ridicule but rather to protect potential victims by warning them of the danger that these offenders pose. Undoubtedly, however, the risk of stigmatization attaches to those who are subject to such penalties (Kelley 1989: 775).

Indeed, aside from the desired public-protection effect, these types of shame penalties may also be attractive to judges and the public because they appear to satisfy the punitive retributive impulse on at least two levels (Karp 1998: 277-8). On one level, there is the practical imposition of some form of suffering in the threat of stigma and social exclusion. On the second level, they are symbolic of the moral and public condemnation of the offence (Tavuchis 1991). ${ }^{14}$

\section{Popular responses}

Disintegrative shaming practices are also evidenced at a more basic level in the media and public response to sexual offending. The recent press and public campaigns for the 'naming and shaming' of paedophiles provide a microcosm for the analysis of popular responses to the perceived threat posed by released sex offenders.

The immediate context of the News of the World's 'name and shame' campaign was the abduction and murder of eight-year-old Sarah Payne in Sussex in July 2000. The campaign centred on the 'outing' of suspected and known paedophiles by printing their photographs, names and addresses, along with brief details of their offending history.

\footnotetext{
${ }^{13}$ State v. Bateman 95 Or. Ct. App. 456, 771 P.2d 314 (1989).

${ }^{14}$ Not surprisingly, several American commentators have questioned whether this is appropriate terrain for judges. Indeed, these measures, like registration and notification measures generally, have been met with both constitutional and non-constitutional challenges (Brilliant 1989; Kelley 1989).
} 
The newspaper promised to continue publishing such details until they had 'named and shamed' all of the child sex offenders in Britain. ${ }^{15}$

This media crusade provoked widespread hysteria and vigilante activity in Portsmouth, where a number of residents protested nightly at the presence of paedophiles in their community and the failure of the authorities to notify them of their whereabouts. During this time, protesters demonstrated outside the homes of suspected paedophiles, daubed slogans on their walls, issued threats and overturned and burned cars. As a result of this activity, several families fled, one convicted paedophile disappeared and two alleged paedophiles committed suicide (Ashenden 2002: 208). ${ }^{16}$

The aftermath of the Sarah Payne case is clearly illustrative of the fact that disintegrative shaming may lead to harassment or even physical attack by vengeful members of the community on suspected paedophiles. Stigmatization of the offender, however, in the form of both state-led and popular responses to sexual offending, may have a number of other harmful consequences for the offender.

\section{The disintegrative effects of 'naming and shaming'}

Far from achieving the goal of successful social reintegration, measures such as registration and notification and novel probation conditions, in common with popular 'name and shame' campaigns, may only serve to label and stigmatize the offender and isolate him or her from the rest of the community (Winick 1998: 539, 556). This singling-out of the offender may have a significant negative effect on at least four fronts. First, it may impede his or her successful reintegration into the community, his or her ability to get a job or accommodation and, therefore, his or her ultimate rehabilitation (Bedarf 1995: 885, 910-11; Cobley 1997: 103; Soothill and Francis 1998: 291). Secondly, heightening the offender's sense of isolation may ultimately increase the chance of subsequent delinquent behaviour as a coping mechanism (Edwards and Hensley 2001: 501). To return to the language of shame, these measures rebuke both offender and offence (Presser and Gunnison 1999: 309), which may foster the 'adoption of a delinquent identity' (Braithwaite and Mugford 1994: 146). Thirdly, from the 'deviancy amplification spiral ${ }^{17}$ of the labelling perspective (Wilkins 1964), the offender who is isolated from 'normal' law-abiding society may be forced to associate with similar offenders, where he or she will learn more sophisticated techniques. Fourthly, if an offender becomes ostracized in the area where he or she lives, then he or she will simply go underground, where he or she could be of even greater danger and commit crime elsewhere (Hebenton and Thomas 1996b: 20, 25; Soothill and Francis 1998: 288-9).

\footnotetext{
${ }^{15}$ Accompanying this was a demand for 'Sarah's Law', to be the equivalent of 'Megan's Law' in the United States, which provides for a much greater degree of community notification. This new package of laws, currently contained in the Sexual Offences Act 2003, comprises a number of key elements, including stricter rules on registration of sex offenders and new sentencing powers for the courts.

16 'Paedophile Kills Himself after Mob Attacks his Home', The Mirror, 9 August 2000.

${ }^{17}$ The amplification spiral begins when society becomes less tolerant of particular forms of behaviour. This leads to more acts' being defined as deviant, since people are now more conscious of this behaviour. As a result, there is more action against criminals who are more severely punished or segregated, and more alienation of deviant groups who now only mix with one another. In turn, this generates more crime by deviant groups. The net result is even less tolerance of deviants by conforming society and the process begins all over again.
} 
Therefore, consistent with Braithwaite's thesis of shaming, disintegrative shaming practices in the form of coercive criminal justice responses will not deter offenders, protect victims or make significant reductions in recidivism levels, except perhaps in the very short term. Without structured support programmes in the community to assist in offender readjustment, to help them to desist, and victims to protect themselves, arrest, prosecution and conviction via the criminal-justice system may result in more incidents of sexual offences in the long term (Finstad 1990; Braithwaite and Daly 1994; Hudson 1998: 237).

It may be, however, that the negative feelings and emotions about sexual offenders can be used more effectively. In a number of jurisdictions, communities have adopted innovative reintegrative shaming practices with sexual offenders, with the broad aims of reducing the incidence of child sexual abuse, preventing future offending and reintegrating the offender back into the community.

\section{Part III: Reintegrative Shaming Practices}

Though restorative programmes for sex offenders are in short supply, a few have been developed which emphasize both treatment and reintegrative principles. In the United States, several states have developed dynamic ways of treating and supporting sexual offenders in the community (Knopp 1991: 191; Zehr 1995: 208). These include, most notably, 'The Safer Society Program' (Knopp 1991) and 'The Stop It Now Program'. ${ }^{18}$

Perhaps one of the best-known schemes is the 'Community Reintegration Project' provided by the Correctional Service of Canada, which operates circles of support and accountability with selected sexual offenders who are considered at high risk of reoffending and who are re-entering the community on release from prison (Cesaroni 2001; Wilson et al. 2002; Petrunik 2002: 503-5). The scheme, which had its origins in the restorative work of the Canadian Mennonite Church, operates as a means of addressing offenders' needs and public concerns surrounding the reintegration of offenders. It is proposed to thematically discuss 'circles' as an illustration of how such schemes as a whole meet the aims of reintegrative shaming which were outlined at the beginning of this piece.

\section{Circles of support and accountability}

First, circles of support are accompanied by one of the principal hallmarks of reintegrative shame cultures-the aim to control wrongdoers within a communitarian society and informally sanction deviance by reintegration into cohesive networks, rather than by formal restraint (Braithwaite 1989: 84-5). The circle is focused on the development of a network of informal support and treatment built around the offender, the core member, involving the wider community in tandem with state and voluntary agencies. Circles of support seek to create a strong identification between the shamed offender and other members of the community where there is a clear emphasis on intimate faceto-face associations, interdependence and cooperation. Unlike legislative and judicial shame penalties which prescribe the sanction but leave the shaming to the community at large, reintegrative shaming mechanisms bring relevant community members

\footnotetext{
${ }^{18}$ http://www.stopitnow.com.
} 
together in an organized forum that evokes shame in the offender and promotes reintegration.

Once the circle is established, members are involved in assisting the offender with reintegration in a number of ways, from helping him or her to find housing and employment to helping to change his or her attitudes and behaviour, and avoid situations that might lead to re-offending (Petrunik 2002: 504). The offender and other members of the circle enter into a signed covenant, which operates as a reintegrative plan of action and specifies each member's area of assistance. The offender agrees to relate to the circle of support and accept its help and advice, to pursue a pre-determined course of treatment and to act responsibly in the community. Offenders are thus more likely to experience shame in an intimate small-group setting like circles of support than in an undifferentiated mass society where shame penalties may miss the mark by failing to create an appropriate and conducive context for shaming (Karp 1998: 290).

Secondly, circles of support also meet both facets of reintegrative shaming: (1) the overt disapproval of the delinquent act (shaming) by socially significant members; and (2) the on-going inclusion of the offender within an interdependent relationship (reintegration) (Zhang 1995: 251). In relation to the first of these elements, the circles consist of four to seven core members, drawn from the local community-usually members of a church or religious faith group (Petrunik 2002: 504). This inner circle may also be supplemented by an outer circle consisting of police, social workers and significant others, such as family and friends, who sit in occasionally, as needed (Petrunik 2002: 504). In relation to the second of these elements, the offender has contact with someone from the circle each day in the high-risk phase just after release. All members meet weekly to discuss any issues which may have arisen and need to be addressed. The life of a circle extends as long as the risk to the community and the offender is above average.

Thirdly, reintegrative shaming is accomplished when four conditions are fulfilled (Braithwaite 1989: 100-1). These are also evident in circles of support and accountability:

(1) the shaming maintains bonds of love or respect between the person being shamed and the person doing the shaming-this is demonstrated by the dual commitment on the part of the offender and the other circle members, which is encapsulated in the signed covenant;

(2) the shaming is directed at the evil of the act rather than the evil of the personthe circle confronts offenders about their deviant attitudes and behaviour and holds them accountable to the community and their commitment not to re-offend;

(3) the shaming is delivered in a context of general social approval-the scheme provides intensive support, guidance and supervision for the offender, mediating between the police, media and the general community to minimize risk and assist in reintegration; and, finally,

(4) the shaming is terminated with gestures or ceremonies of acceptance and forgiveness - the net result is that sex offenders receive sympathy and help in reintegration, and not just hostility, from at least some members of the community.

In the words of Petrunik:

... [r] ather than being driven from neighborhood to neighborhood like some tormented Frankenstein and perhaps re-offending in despair that he can never be any different, the sex offender is given a chance to redeem himself under the caring but ever so watchful eyes of a concerned community. (2002: 506) 


\section{The application of reintegrative shaming practices in the United Kingdom}

In terms of how such reintegrative shaming practices with sex offenders could actually operate in practice in the United Kingdom, there are two main possibilities. One is as an avenue to diversionary treatment. As an alternative to the traditional criminal-justice system, sexual offenders would forego criminal prosecution in exchange for undergoing a treatment and support programme. The other main possibility is to prosecute all but the most minor sexual offences and then put this new system into operational effect after the convicted offender is released from prison. In this instance, it would operate as an addition rather than as an alternative to custody.

As outlined at the outset of the article, restorative approaches advocate that the opinion of victims and their families should be taken into account. There are two competing views which victims may have, however, which are difficult to reconcile in any system of justice. On the one hand, some victims of intra-familial abuse, in common with domesticabuse victims, may want to see the offender punished or vilified but, more commonly, they simply want the abuse to stop (Carbonatto 1995; 1998; Hoyle 1998). On the other hand, for many other victims, particularly those who have been abused or assaulted by strangers - the victims of extra-familial abuse-the expressive functions of punishment in public and state condemnation of the offence are an important part of the healing and vindication process (Morris and Gelsthorpe 2000: 412; Hudson 2002: 622; Wright 2002: 664). In the latter instance, a diversionary scheme may unjustly release the offender from criminal prosecution. In the former instance, it may act as a powerful incentive to offenders' coming forward to seek help.

In this respect, it is contended that the better approach would be to process formally all but the most minor of sexual offences through the criminal-justice system initially. Informal programmes of support and treatment in the community would then be available on release from custody on the basis of a referral by a statutory criminal-justice agency. Perhaps such schemes could be integrated into existing inter-agency riskassessment procedures, where recommendations could be made about how to process the case and where the various agencies would agree a restorative response. Schemes could also be developed as part of the offender's programme of supervision or treatment in the community and, in common with current arrangements, would address all aspects of the offender's life necessary for successful reintegration including finding suitable accommodation and employment, and not just their abusive behaviour.

The participation of victims and offenders, however, must be voluntary and either party should have the right to opt out of the process at any stage. To force victims to participate would lead to further victimization and disempowerment. To force offenders to participate in programmes may be futile, since the research evidence suggests that the effectiveness of interventions is often increased when offenders become involved voluntarily (McIvor 1992; McLaren 1992; McGuire 1995). ${ }^{19}$

Before outlining the possible benefits which such schemes could have in terms of the effective management of sexual offenders in the community, there are a number of obvious caveats. First, as yet, there are no longitudinal studies available to establish with

\footnotetext{
${ }^{19}$ Although non-coercive practice is often cited as one of the key principles which underpin restorative practices, there is an increasing honesty within restorative thinking that coercion is never truly absent from restorative processes. If an individual is given the choice between a sentence of imprisonment or engagement in a restorative programme, it is a fallacy to say that this does not involve at least some element of latent coercion.
} 
THE USE OF 'SHAME' WITH SEXUAL OFFENDERS

any certainty how effective these treatments are in terms of recidivism rates following participation in a programme. ${ }^{20}$ Secondly, there are the logistical problems of ensuring sufficient availability of programmes with suitably qualified staff, and the monitoring and evaluation of programmes which ensure genuine engagement on the part of the offender. As will be discussed below, the overwhelming positive aspect of these schemes, however, is the fact that they encourage and facilitate the treatment and reintegration of the offender and provide some level of engagement and truth for the parties about what has happened.

\section{Part IV: Reintegrative Justice and Child Sexual Offences-Addressing the Critics}

This next section seeks to initially address some of the major criticisms of restorative justice as a whole, as it is applied to child sexual offences, before turning attention to the potential problems associated with shaming mechanisms in particular.

\section{Restorative justice}

Opponents of restorative justice have pointed out the dangers inherent in a communitarian approach to justice generally-principally, the need to ensure legitimacy (Paternoster et al. 1997), accountability (Roche 2003) and adequate safeguards (Ashworth 2002; Hudson 2002; Wright 2002). Those who do accept its usefulness and viability for particular types of offences, usually low-level crime, and for particular classes of offenders, most notably first-time and young offenders, are more reticent to extend this paradigm to serious and persistent forms of offending (Johnstone 2003).

Proponents such as Hudson (1998; 2002), Morris and Gelsthorpe (Morris and Gelsthorpe 2000; Morris 2002) and Daly (2000; 2002), among others, have significantly advanced the case for the application of restorative justice to sexual and violent (and racial) crime. However, their work, for the most part, has been concentrated upon domestic violence with brief reference to child sexual abuse. This section of the article will attempt to extend this thinking and apply the principles of restorative justice to the perpetrators of child sexual abuse.

It will be demonstrated that the case for restorative justice as applied to 'gendered and sexualised violence' (Hudson 2002) commonly rests on the alleged failure of established formal criminal justice to provide effective remedies for victims and the greater potential of restorative justice for providing satisfactory outcomes in more cases (Hudson 2002: 621).

Indeed, Morris and Gelsthorpe have summarized the particular set of characteristics which underlie family violence which, they argue, seem to be perpetuated by the use of conventional criminal-justice processes and which make it particularly suitable for a restorative approach. Although these comments were made in the context of domestic abuse, it is argued here that these could apply equally to victims of child sexual abuse:

\footnotetext{
${ }^{20}$ A recent evaluation of circles in Ontario found offenders receiving assistance via a circle re-offended at a lower rate incrementally in comparison with a matched control sample. In comparing the expected recidivism rate with the observed rate, recidivism was reduced by more than 50\% (Wilson et al. 2002: 378). Further, from a harm-reduction perspective, each incident of sexual recidivism was categorically less invasive and severe than the offence for which the offender had most recently been imprisoned (Wilson et al. 2002: 378).
} 
... the existence of a prior relationship between the parties; the fact that the parties have lived together and may wish to continue living together; the likelihood of repeat victimisation; the context of emotional abuse and ongoing power imbalances in the relationship; the victim's fear of the offender; the secrecy of the violence; the isolation of the victim; and the offender's minimising of the seriousness of the violence. (2000: 421)

It is proposed to further discuss several of these elements as they apply to child sexual abuse and the potential difficulties which they pose for restorative approaches.

First, one of the main criticisms levelled against the use of restorative justice with sexual offences is that it may minimize or trivialize what are very serious criminal offences, particularly where children and the vulnerable are concerned (Hudson 1998: 253; Morris and Gelsthorpe 2000: 417-18; Morris 2002: 603). Critics suggest that such offences are too grave or sensitive to be dealt with by means other than the traditional criminaljustice system and that nothing should be done which might return them to the status of a 'private' matter.

The use of the restorative process, however, does not signify the decriminalization of sexual offences. The criminal law remains as a signifier and a denouncer, but the belief within restorative processes is that the abuser's family and friends are far more potent agents to achieve this objective of denunciation and of mobilizing censure (Morris and Gelsthorpe 2000: 418; Morris 2002: 603). In this way, restorative approaches also have the potential to challenge community norms and values about what is acceptable behaviour and to make sure that deviant sexual behaviour is something which is strongly disapproved of and about which perpetrators feel a strong sense of shame (Hudson 1998: 250, 254; Karp 1998: 280; Morris and Gelsthorpe 2000: 418). In addition, as discussed above, a system which makes provision for state intervention as the formal backdrop for more informal processes is clearly workable within the restorative framework.

A second concern is that restorative justice fails to promote offender accountability and allows the offender to reject responsibility for the offence (Morris and Gelsthorpe 2000: 417). However, most offenders are not made accountable for acts of abuse or rape against intimates (Braithwaite and Daly 1994: 191-2; Morris and Gelsthorpe 2000: 415). For every paedophile known to the police, there are ten more not identified (Leggett 2000: 7). In addition, a high proportion of child victims-figures suggest between 80 (Grubin 1998: 15) and 98 per cent (Leggett 2000: 7)—are abused by someone known to them rather than predatory strangers. ${ }^{21}$ The possibility of a parent or other relative being labelled and singled out for public harassment and rejection may impede the sexually abused victim, particularly children, from coming forward in the first place and reporting the incident.

Restorative or reintegrative programmes may ultimately break cycles of abuse and help the offender to desist, more so than stigmatizing the offender through punitive control in the community mechanisms such as registration and notification. If an offender knows that he or she may not face the possibility of a criminal prosecution or ultimately a prison sentence if he or she comes forward, then more offenders may be willing to come out in the open, admit to their crimes and seek treatment. The availability of a restorative option may also encourage more victims to come forward and

\footnotetext{
${ }^{21}$ Jackson and Scott (1999: 92-3) point out that media coverage of the risks posed by adults to children 'reverse [s] the order of danger' in that so-called 'stranger danger' is given more media coverage than cases of assault upon children by intimates.
} 
report the offence. Increasing numbers of offenders, therefore, would be made accountable for their offences. This in turn could have the net result of reducing the incidence of child sexual abuse.

Moreover, those offenders who are arrested and prosecuted for sexual abuse against children may have ingrained patterns of abusing and assaulting the vulnerable which the criminal-justice system does little to address (Braithwaite and Daly 1994: 191-2). The restorative process also offers a way to confront the offender about both the factors underlying his or her offending and the consequences of his or her offending behaviour for the victim in particular (Morris 2002: 603). The offender is expected to accept responsibility for the abuse and techniques of neutralization can be challenged (Morris and Gelsthorpe 2000: 417). Contrition and apology-key elements in the restorative approach-may be part of the cycle of abuse. The difference in restorative processes is that the 'public' nature of that contrition and apology and the shared monitoring of subsequent events help to ensure that it is 'real' (Morris and Gelsthorpe 2000: 417).

A third major criticism which is often put forward against the use of restorative justice with sexual offences is that many forms of sexual violence and assault such as rape or child sexual abuse are about power and control. To confront the victim of a sexual offence with his or her offender may serve to reproduce and reinforce the imbalance of power entrenched in abusive relationships and lead to possible re-victimization (Martin 1996; Hudson, 1998: 247; Morris and Gelsthorpe 2000: 416-17). With children in particular, there is the risk that the unequal power relationships between child victims and adult perpetrators of sexual offences may be further increased.

One could argue, however, that there is always a power imbalance between offenders and victims, as offenders have 'taken' from victims (Morris and Gelsthorpe 2000: 424, n. 18) and that it is the conventions of present formal criminal law and punishment which reproduce the power relations that produce violent and sexual crime (Hudson 1998: 249). Restorative justice processes and practices, however, routinely work towards removing this imbalance by focusing on the empowerment of victims.

With restorative justice, the victim's perspective is made central to the proceedings, whereas it is only a source of evidence in criminal cases (Hulsman 1991: 681; Hudson 1998: 248). Restorative processes could provide a forum in which the victim can make clear to the offender the effects of the abuse on him or her (Morris 2002: 608). Friends and families can help to reduce the victim's feeling of isolation by providing a supportive basis for that voice to be heard (Morris and Gelsthorpe 2000: 417). Offenders can also give victims some insight into the reasons for their offending. The personal experience of seeing that the offender is affected by a genuine feeling of remorse and shame should have a healing and restorative effect for the victim (Walgrave and Aersten 1996: 77).

A fourth and related criticism levelled against restorative justice in this context is that it may encourage victims to remain in abusive situations and cause repeat victimization. An implicit or underlying assumption when parties seek legal remedies is that where there was a relationship, it has broken down and contact is not desired (Morris and Gelsthorpe 2000: 419). However, as mentioned above, this is not necessarily so when women are assaulted by their partners or children are abused by their parents. Indeed, a principal argument presented in support of the use of restorative processes with respect to child sexual abuse is that many children, for a range of reasons, wish to remain in or return to the family home and it is often desirable for them to do so (Hudson 2002: 622). By offering constructive rather than penal solutions, restorative processes may 
also be opted for at an earlier stage in children's experience of sexual abuse (Morris and Gelsthorpe 2000: 422).

Moreover, restorative justice may actually increase the safety of child victims (Morris and Gelsthorpe 2000: 420). As mentioned at the outset of this article, in debates about social ordering, the concept of risk increasingly furnishes a discursive framework with which 'responses to problems' are being considered (Beck 1992; Parton et al. 1997). In line with Ericson and Haggerty's (1997) theory of 'knowledge-risk-security', which refers to the current concern with garnering knowledge about offenders in the community in order to control risk and increase security, the public are admitted as consumers of this knowledge (Reiss 1989; Hebenton and Thomas 1996a: 108; 1996b: 431). This 'opening up' of knowledge and awareness on the part of the community is especially important when one considers that many sexual offenders are manipulative and devious by nature and will seek to infiltrate unsuspecting families. Many sexual offenders seek to 'groom' children for sexual purposes. Criminal-justice interventions can do little to prevent this, unless the offender has already come to their attention. Communities can, however, by arranging networks of support and control, where necessary. Braithwaite, for instance, uses the example of 'Uncle Harry' as a 'significant other' of the offender and says that 'Uncle Harrys' have a more plural range of incapacitative keys that they can turn than a prison guard who can just turn one key (1999: 67; Ashworth 2002: 589-90).

A fifth concern which has arisen is that restorative justice encourages vigilantism (Morris and Gelsthorpe 2000: 420) because of its association with community or popular justice..$^{22}$ As Ashenden puts it " $[\mathrm{t}]$ he underside . . . is the "danger" of . . vigilance turning into vigilante action' (2002: 203). As demonstrated above in relation to popular responses to sexual offending in the form of 'name and shame' campaigns, community justice can be repressive, retributive and vengeful (Morris 2002: 609). These values, however, are fundamentally at odds with the defining values of restorative justice and cannot, therefore, be part of it (Morris and Gelsthorpe 2000: 420).

On the other hand, the schemes which have developed thus far, albeit on an ad hoc basis, should inspire confidence that the community is capable of responding to delicate issues surrounding the reintegration of sexual offenders in the community in a responsible and constructive manner. Operating programmes on the basis of a referral by statutory agencies will ensure the provision of adequate safeguards and standards and that individuals who claim that their human rights have been infringed may be able to seek a direct remedy against a public authority under the Human Rights Act 1998. Formal law could stand behind restorative justice procedures as a guarantor of rights which cannot be overridden by decisions arrived at by consensus or majority (Hudson 1998: 256). As such, if there were concerns about communities' taking over this process for non-restorative processes, checks could be introduced.

Furthermore, if properly operated and applied, restorative justice schemes may also provide a process of education and engagement for vigilante groups, as well as an opportunity for the wider community to approach the problem of managing sexual offenders in the community in a more considered way. Vengeful community attitudes often make the work of statutory and voluntary agencies in the resettlement of the

\footnotetext{
${ }^{22}$ Von Hirsch and Ashworth (1998: 303) certainly justify conventional justice practices on the grounds that they displace vigilantism and prevent people from taking the law into their own hands.
} 
THE USE OF 'SHAME' WITH SEXUAL OFFENDERS

offender extremely difficult. Restorative approaches, in this way, may serve to facilitate an effective partnership approach between the statutory, voluntary and community sector in responding to contentious sexual offender issues.

\section{Shaming}

In addition to the broader commentary on restorative justice, there is a related debate on shame within restorative-justice literature. ${ }^{23}$ A central critical tenet is the difficulty of implementing shaming sanctions in practice in contemporary Western society, where three broad critiques emerge.

First, reintegrative shaming theory has been the subject of only limited empirical testing (Makkai and Braithwaite 1994; Zhang 1995; Vagg 1998; Hay 2001). Of these studies, only a few have explicitly examined the effects of reintegrative shaming on subsequent delinquent behaviour (Zhang 1995; Vagg 1998; Hay 2001). What little research there is on shaming has been done in the context of classic shame cultures such as Iceland, Japan and Hong Kong and, as will be discussed further below, there are obvious limitations here in extrapolating these findings to mainstream Western society. ${ }^{24}$ Furthermore, studies have generally been confined to young offenders (Maxwell and Morris 1999; 2002; Olthof 2000) and to less serious crimes.

Rates of reoffending are of course only one measure of offender reintegration. As argued above in relation to restorative schemes as a whole, there is a need for careful experiment and periodical evaluation of reintegrative shaming mechanisms with sex offenders whose remit is broader than a consideration of recidivism rates but which also focuses on the consequences of offending for all concerned-for families, communities and the victim, as well as the offender (Christie 1977; Maxwell and Morris 1999; 2002).

A second and related critical issue is that the cultural and societal conditions which are necessary for reintegrative shaming to work and which are evident in paradigmatic shame cultures like pre-World War II Japan (Benedict 1946) are lacking in modern society. Instead, most Western societies are characterized more by individualism than communitarianism and they lack social and norm cohesion (Tavuchis 1991). The extent of cultural pluralism and complexity also means that the cultural meaning of shame is highly ambiguous and amorphous (Massaro 1991: 1922-4; 1939; Karp 1998: 289). ${ }^{25}$

However, as Ian Hacking (1999) has pointed out, in an age in which we are supposedly drowning in value-relativism, there is striking consensus concerning the wrongness of sexual contacts and relationships between adults and children. Popular responses to sexual offending show that the community is somewhat ahead of judicial attitudes, with public criticism of lenient sentences for rape and the early release of high-risk offenders. The 'name and shame' campaigns discussed above show that the community is, if anything, too strong in its disapproval of offending behaviour and would certainly be

\footnotetext{
${ }^{23}$ A number of critical fronts have developed, including the theoretical distinctions between shame and guilt (Lewis 1971; Taylor 2002; Harris et al. 2004) and shaming as a psychological process (Tomkins 1987; Olthof 2000).

${ }^{24}$ There is some evidence that communitarian societies (as defined by Braithwaite) have lower crime rates than other societies (Messner and Rosenfeld 1997; Savolainen 2000). However, research also shows that the recidivism rates of countries such as Iceland (Baumer et al. 2002) and Japan (Japanese Ministry of Justice 1998) closely approximate those of other countries which were much less communitarian and socially integrated. Furthermore, Hong Kong has a high level of intolerance for deviant behaviour, which results potentially in labelling and exclusion of those who are non-conformist (Vagg 1998).

${ }^{25}$ A related argument here in relation to community disapproval of deviant conduct is that there are also problems in identifying the relevant 'community' and securing its participation, representation and cooperation (Hudson 1998: 251; Crawford 1999: 148-201).
} 
able to express strong enough censure to induce the necessary shame in the offender (Hudson 1998: 249).

A third problem is the recovery of a culture of social inclusion which would underpin and support the development of processes whose outcome is shaming that is reintegrative rather than eliminative, and where the ultimate goal is the enhancement of social justice. It has been argued that the creation of such a culture, which is not easy to envisage in present-day Britain and America, is the most intractable problem in the path of restorative justice' (Hudson 1998: 256).

This argument underlines the necessity of a rigorous public-education and awareness programme, driven by government, designed to provide accurate information. Such a programme would hopefully shift cultural attitudes, dispel the commonly-held myths and misconceptions, and increase public understanding of the real nature of sexual offenders and sexual offending (Grubin 1998; Leggett 2000). ${ }^{26}$ Through the dissemination and digestion of this information, communities will feel empowered to take responsibility for the protection of their own children. By adopting such an approach, the community itself has an involvement, thus reducing the social exclusion and stigmatization of offenders that can lead to further offending. There is also less chance that the offender will go underground, where he or she may be of even greater danger to unsuspecting individuals and where risk is effectively displaced to another community.

\section{Conclusion}

In conclusion, it is acknowledged that the creation of sexual offenders as the ultimate demon and the current law-and-order ideology of crime control, incapacitation and risk management, common to many jurisdictions, may not rest easily with the advocacy of a therapeutic response. On the other hand, it has also been demonstrated that a further unwanted consequence of disintegrative shaming is that sexual-offending behaviour may be increased if the offender feels socially isolated. Reintegrative shaming schemes could have the double benefit of protecting children from abuse and the offender from vigilante attack and also helping him or her to adjust to the demands of living on the outside. Such programmes may not be appropriate for all sex offenders, particularly high-risk offenders, but they may provide an effective alternative for low-to-middle-risk offenders, particularly in the context of intra-familial abuse and when operated on a voluntary basis.

The restorative or reintegrative justice paradigm does not have all the answers. It is often met with controversy, particularly where 'gendered and sexualised violence' (Hudson 2002) is concerned. In the absence of workable alternatives, however, there is a need to extend the use of restorative justice to the most difficult of societal problems, like child sexual abusers and child sexual abuse. Its potential benefits for improving the safety of victims, for providing relief for communities and for rehabilitating offenders may mean that it is worth careful experiment.

\footnotetext{
${ }^{26}$ Some of the issues which the community should be educated about include the following: the abuser is rarely the 'dirty old man' in the raincoat lurking in school playground; most sexual abuse is committed by people known to the child; sexual abusers are men and women and, in a growing number of cases, adolescents or children; not all sexual offenders pose the same degree of high risk; and that recidivism research has shown that most sexual offenders will not reoffend given appropriate treatment and support (Grubin 1998).
} 
THE USE OF 'SHAME' WITH SEXUAL OFFENDERS

\section{REFERENCES}

Ahmed, E., Harris, N., Braithwaite, J. and Braithwatte, V., eds (2001), Shame Management Through Reintegration. Cambridge: Cambridge University Press.

Ashenden, S. (2002), 'Policing Perversion: The Contemporary Governance of Paedophilia', Cultural Values, 6: 197-122.

Ashworth, A. (2002), 'Responsibilities, Rights and Restorative Justice', British Journal of Criminology, 42: 578-95.

Barnett, R. E. (2003), 'Restitution: A New paradigm of Criminal Justice', in G. Johnstone, ed., A Restorative Justice Reader: Texts, Sources, Context. Devon: Willan Publishing.

Baumer, E. P., Wright, R., Kristinsdottir, K. and Gunnlaugsson, H. (2002), 'Crime, Shame and Recidivism', British Journal of Criminology, 42:40-59.

Bazemore, G. (1996), 'Three Paradigms for Juvenile Justice', in B. Galaway and J. Hudson, eds, Restorative Justice: International Perspectives. Monsey, NY: Criminal Justice Press.

Beck, U. (1992), Risk Society: Towards a New Modernity. London: Sage.

Becker, H. (1963), Outsiders: Studies in the Sociology of Deviance. New York: The Free Press of Glencoe.

- (1974), 'Labelling Theory Reconsidered', in P. Rock and M. McIntosh, eds, Deviance and Social Control. London: Tavistock.

Bedarf, A. (1995), 'Examining Sex Offender Community Notification Laws', California Law Review, 83: 885-939.

Benedict, R. (1946), The Chrysanthemum and the Sword: Patterns of Japanese Culture. London: Routledge and Kegan Paul.

Botтoms, A. E. (1995), 'The Philosophy and Politics of Punishment and Sentencing', in C. Clarkson and R. Morgan, eds, The Politics of Sentencing Reform. Oxford: Oxford University Press.

Boyes-Watson, C. (1999), 'In the Belly of the Beast? Exploring the Dilemmas of StateSponsored Restorative Justice', Contemporary Justice Review, 2: 261-81.

Braithwaite, J. (1989), Crime, Shame and Reintegration. Sydney: Cambridge University Press.

—_(1993), 'Shame and Modernity', British Journal of Criminology, 33: 1-18.

- (1999), 'Restorative Justice: Assessing Optimistic and Pessimistic Accounts', in M. Tonry, ed., Crime and Justice: A Review of Research, 25: 1-27. Chicago: Chicago University Press.

- (2000), 'The New Regulatory State and the Transformation of Criminology', British Journal of Criminology, 40: 222-38.

Braithwaite, J. and Daly, K. (1994), 'Masculinities, Violence and Communitarian Control', in T. Newburn and E. Stanko, eds, Just Boys Doing Business? Men, Masculinity and Crime. London: Routledge.

Bratthwaite, J. and Mugford, S. (1994), 'Conditions of Successful Reintegration Ceremonies', British Journal of Criminology, 34: 139-71.

Brilliant, J. A. (1989), 'The Modern Day Scarlet Letter: A Critical Analysis of Modern Probation Conditions', Duke Law Journal, 1357-58.

Carbonatto, H. (1995), Expanding Intervention Options for Spousal Abuse: The Use of Restorative Justice, Occasional papers in Criminology New Series: No. 4. Wellington, New Zealand: Institute of Criminology, Victoria University of Wellington.

- (1998), The Criminal Justice Response to Domestic Violence in New Zealand, Criminology New Zealand (a newsletter from the Institute of Criminology, Victoria University of Wellington), 10: 7-8. 
Cesaroni, C. (2001), 'Releasing Sex Offenders into the Community Through "Circles of Support": A Means of Reintegrating the "Worst of the Worst" , Journal of Offender Rehabilitation, 34: 85-98.

Christie, N. (1977), 'Conflicts as Property', British Journal of Criminology, 17: 1-15.

Cobley, C. (1997), 'Sentencing and Supervision of Sex Offenders', Journal of Social Welfare and Family Law, 19: 98-104.

Consedine, J. (1995), Restorative Justice: Healing the Effects of the Crime. Lyttleton: Ploughshares Publications.

Crawford, A. (1999), The Local Governance of Crime: Appeals to Community and Partnerships. Oxford: Oxford University Press.

Daly, K. (2000), 'Revisiting the Relationship between Retributive and Restorative Justice', in J. Braithwaite and H. Strang, eds, Restorative Justice: Philosophy to Practice. Aldershot: Ashgate.

- 2002), 'Sexual Assault and Restorative Justice', in H. Strang and J. Braithwaite, eds, Restorative Justice and Family Violence. Melbourne: Cambridge University Press.

DAvIs, G. (1992), Making Amends: Mediation and Reparation in Criminal Justice. London and New York: Routledge.

Duff, A. (2002), 'Restorative Punishment and Punitive Restoration', in L. Walgrave, ed., Restorative Justice and the Law. Devon: Willan Publishing.

Earl-Hubbard, M. (1996), 'The Child Sex Offender Registration Laws: The Punishment, Liberty, Deprivation and Unintended Results Associated with the Scarlet Letter Laws of the 1990s', North Western Law Review, 90: 788-862.

Edwards, W. and Hensley, C. (2001), 'Contextualising Sex Offender Management Legislation and Policy: Evaluating The Problem of Latent Consequences in Community Notification Laws', International Journal of Offender Therapy and Comparative Criminology, 45: 83-101.

Ericson, R. V. and Haggerty, K. D. (1997), Policing the Risk Society. Oxford: Clarendon Press.

Falshaw, L., Friendship, C. and Bates, A. (2003), Sexual Offenders: Measuring Reconviction, Reoffending and Recidivism, Home Office Research Findings No. 183. London: Home Office, RDS Directorate.

Feeley, M. and Simon, J. (1992), 'The New Penology: Notes on the Emerging Strategy of Corrections and Its Implications', Criminology, 30: 449-74.

- (1994), 'Actuarial Justice: Power/Knowledge in Contemporary Criminal Justice', in D. Nelken, ed., The Futures of Criminology. London: Sage.

Finstad, L. (1990), 'Sexual Offenders Out of Prison: Principles for a Realistic Utopia', International Journal of the Sociology, 18: 157-77.

Foucault, M. (1977), Discipline and Punish: The Birth of the Prison. London: Penguin.

Garfinkel, H. (1956), 'Conditions of Successful Degradation Ceremonies', American Journal of Criminology, 61: 420-4.

Garland, D. (1996), 'The Limits of the Sovereign State: Strategies of Crime Control in Contemporary Society', British Journal of Criminology, 36: 445-71.

- (2001), The Culture of Control: Crime and Social Order in Contemporary Society. Chicago: University of Chicago Press.

Grubin, D. (1998), Sex Offending against Children: Understanding the Risk, Police Research Series Paper 99. London: Home Office, Policing and Reducing Crime Unit, RDS Directorate.

Hacking, I. (1999), The Social Construction of What? Cambridge, MA: Harvard University Press.

Harris, N., Walgrave, L., and Braithwaite, J. (2004), 'Emotional Dynamics in Restorative Conferences', Theoretical Criminology, 8: 191-210. 
THE USE OF 'SHAME' WITH SEXUAL OFFENDERS

Hawthorne, N. (1994, first published in 1850), The Scarlet Letter. London, New York: Penguin Books Ltd.

HAY, C. (2001), 'An Exploratory Test of Braithwaite's Reintegrative Shaming Theory', Crime and Delinquency, 38: 132-53.

Hebenton, B. and Thomas, T. (1996a), 'Sexual Offenders in the Community: Reflections on Problems of Law, Community and Risk Management in the USA and England and Wales', International Journal of the Sociology of Law, 24: 427-43.

- $(1996 b)$, 'Stranger Danger', Criminal Justice Matters, Autumn, 25.

Herman, J. (1997), Trauma and Recovery. New York: Basic Books.

Home Office (1996), Protecting the Public: The Government's Strategy on Crime in England and Wales, Cm 3190. London: HMSO.

Hoyle, C. (1998), Negotiating Domestic Violence: Police, Criminal Justice and Victims. Oxford: Oxford University Press.

Hudson, B. (1998), 'Restorative Justice: The Challenge of Sexual and Racial Violence', Journal of Law and Society, 25: 237-56.

- (2002), 'Restorative Justice and Gendered Violence: Diversion or Effective Justice?', British Journal of Criminology, 42: 616-34.

Hulsman, L. (1991), 'The Abolitionist Case: Alternative Crime Policies', Israeli Law Review, 25: 681-709.

Jackson, S. and Scott, S. (1999), 'Risk Anxiety and the Social Construction of Childhood', in D. Lupton, ed., Risk and Sociocultural Theory: New Directions and Perspectives. Cambridge: Cambridge University Press.

Japanese Ministry of Justice (1998), Summary of the White Paper on Crime, 1998. Tokyo, Japan: Research and Training Institute.

Johnstone, G., ed. (2003), A Restorative Justice Reader: Texts, Sources, Context. Devon: Willan Publishing.

Kahan, D. M. (1996), 'What Do Alternative Sanctions Mean?', University of Chicago Law Review, 63: 591-653.

KARP, D. R. (1998), 'The Judicial and the Judicious Use of Shame Penalties', Crime and Delinquency, 44: 277-94.

Kelley, R. K. (1989) (Comment), 'Sentenced to Wear the Scarlet Letter: Judicial Innovations in Sentencing', Dickinson Law Review, 93: 759-88.

Kimball, C. M. (1996), 'A Modern Day Arthur Dimmesdale: Public Notification When Sex Offenders are Released into the Community', Georgia State University Law Review, 12: $1187-221$.

Knopp, F. H. (1991), 'Community Solutions to Sexual Violence', in H. E. Pepinsky and R. Quinney, eds, Criminology as Peacemaking. Bloomington: Indiana University Press.

Leggett, S. (2000), 'Paedophiles and other Child Abusers', The Ulster Humanist, 5: 7-8.

Levrant, S., Cullen, F. T., Fulton, B. and Wozniak, J. F. (1999), 'Reconsidering Restorative Justice: The Corruption of Benevolence Revisited?', Crime and Delinquency, 45: 3-27.

Lewis, H. B. (1971), Shame and Guilt in Neurosis. New York: International Universities Press.

Logan, W. (1999), 'Liberty Interests in The Preventive State: Procedural Due Process and Sex Offender Community Notification Laws', Journal of Criminal Law and Criminology, 89: 1167-231.

Makkai, T. and Braithwaite, J. (1994), 'Reintegrative Shaming and Compliance with Regulatory Standards', Criminology, 32: 361-85. 
Marshall, T. (1991), Victim-Offender Mediation. Home Office Research Bulletin No. 30. London: HMSO.

- (1999), Restorative Justice: An Overview. A Report by the Home Office Research Development and Statistics Directorate. London: HMSO.

Martin, P. (1996), 'Restorative Justice: A Family Violence Perspective', Social Policy Journal of New Zealand, 6: 56-68.

Massaro, T. M. (1991), 'Shame Culture and American Criminal Law', Michigan Law Review, 89: $1880-944$.

Maxwell, G. and Morris, A. (1999), Understanding Re-offending. Wellington: Institute of Criminology, Victoria University of Wellington.

- (2002), 'The Role of Shame, Guilt and Remorse in Restorative Justice Processes for Young People', in E. Weitekamp and H.-J. Kerner, eds, Restorative Justice: Theoretical Foundations. Devon: Willan Publishing.

(2004), 'What is the Place of Shame In Restorative Justice?', in H. Zehr and B. Toews, eds, Critical Issues in Restorative Justice. Monsey, NY: Criminal Justice Press and Devon: Willan Publishing.

McElreA, F. W. M. (1994), 'Justice in the Community: The New Zealand Experience', in J. Burnside and N. Baker, eds, Relational Justice: Repairing the Breach. Winchester: Waterside Press.

McGuire, J. (1995), What Works: Reducing Re-offending? Chichester: John Wiley.

McIvor, G. (1992), Sentenced to Serve? Aldershot: Gower.

McLaren, K. (1992), Reducing Re-offending: What Works Now? Wellington, New Zealand: Department of Justice.

Messner, S. F. and Rosenfeld, R. (1977), 'Political Restraint of the Market and Levels of Criminal Homicide: A Cross-National Application of Institutional Anomie Theory', Social Forces, 75: 1393-416.

MikA, H. and McEvoy, K. (2001), 'Restorative Justice in Conflict: Paramilitarism, Community and the Construct of Legitimacy in Northern Ireland', Contemporary Justice Review, 4: 292-319.

Morris, A. (2002), 'Critiquing the Critics: A Brief Response to Critics of Restorative Justice', British Journal of Criminology, 42: 596-615.

Morris, A. and Gelsthorpe, L. (2000), 'Re-visioning Men's Violence against Female Partners', The Howard Journal, 39: 412-28.

Morris, A. and Maxwell, G. (2000), 'The Practice of Family Group Conferences in New Zealand: Assessing the Place, Potential and Pitfalls of Restorative Justice', in A. Crawford and J. Goodey, eds, Integrating a Victim Perspective in Criminal Justice. Alsershot: Ashgate.

Olthof, T. (2000), 'Shame, Guilt, Antisocial Behaviour and Juvenile Justice', in I. Weijers and A. Duff, eds, Punishing Juveniles: Principles and Critique. Oxford: Hart Publishing.

O’Malley, P. (1999), 'Volatile Punishments: Contemporary Penality and the Neo-Liberal Government', Theoretical Criminology, 3: 175-96.

Parton, N., Thorpe, D. and Wattam, C. (1997), Child Protection: Risk and the Moral Order. Hampshire: Macmillan.

Paternoster, R., Backman, R., Brame, R., and Sherman, L. (1997), 'Do Fair Procedures Matter? The Effect of Procedural Justice on Spousal Assault', Law and Society Review, 31: 163-204. 
Petrunik, M. G. (2002), 'Managing Unacceptable Risk: Sex Offenders, Community Response, and Social Policy in the United States and Canada', International Journal of Offender Therapy and Comparative Criminology, 46: 483-511.

Presser, L. and Gunnison, E. (1999), 'Strange Bedfellows: Is Sex Offender Notification a Form of Community Justice?', Crime and Delinquency, 45: 299-315.

Reiss, A. (1989), 'The Institutionalisation of Risk', Law and Policy, 11: 392-402.

Retzinger, S. M. and SchefF, T. J. (1996), 'Strategy for Community Conferences: Emotions and Social Bonds', in J. Hudson and B. Galaway, eds, Restorative Justice: International Perspectives. Monsey, NY: Criminal Justice Press.

Roche, D. (2003), Accountability in Restorative Justice. Clarendon Studies in Criminology. Oxford: Oxford University Press.

Rose, N. (2000), 'Government and Control', British Journal of Criminology, 40: 321-39.

Savolainen, J. (2000), 'Inequality, Welfare State, and Homicide: Further Support for the Institutional Anomie Theory', Criminology, 38: 1021-42.

Shearing, C. (2000), 'Punishment and the Changing Face of Governance', Punishment and Society, 203-20.

Soothill, K. and Francis, B. (1998), 'Poisoned Chalice or Just Deserts? (The Sex Offenders Act 1997)', Journal of Forensic Psychiatry, 9: 281-93.

TAvuchis, N. (1991), Mea Culpa: A Sociology of Apology and Reconciliation. Stanford, CA: Stanford University Press.

TAYlor, G. (2002), 'Guilt, Shame and Shaming', in I. Weijers and A. Duff, eds, Punishing Juveniles: Principle and Critique. Oxford: Hart Publishing.

Tomkins, S. S. (1987), 'Shame', in D. L. Nathanson, ed., The Many Faces of Shame. New York: Guildford Press.

Umbreit, M. (1994), Victim Meets the Offender: The Impact of Restorative Justice and Mediation. Monsey, NY: Criminal Justice Press.

VAGG, J. (1998), 'Delinquency and Shame: Data from Hong Kong', British Journal of Criminology, 38: 247-64.

Van Dujn, A. L. (1999), 'The Scarlet Letter Branding', Drake Law Review, 47: 635-59.

Van Ness, D. and Strong, K. H. (1997), Restoring Justice. Cincinnati, OH: Anderson Publishing Co.

Van Sтокком, B. (2002), 'Moral Emotions in Restorative Justice Conferences: Managing Shame, Designing Empathy', Theoretical Criminology, 6: 339-60.

Von-Hirsch, A. and Ashworth, A., eds (1998), Principled Sentencing: Readings on Theory and Policy, 2nd edn. Oxford: Hart.

Walgrave, L. (2003), 'Imposing Restoration Instead of Inflicting Pain', in A. Von Hirsch, J. V. Roberts, A. E. Bottoms, K. Roach and M. Schiff, eds, Restorative Justice and Criminal Justice: Competing or Reconcilable Paradigms? Oxford: Hart Publishing.

Walgrave, L. and Aersten, A. (1996), 'Reintegrative Shaming and Restorative Justice: Interchangeable, Complementary or Different?', European Journal of Criminal Policy and Research, 4: $67-85$.

Wilkins, L. (1964), Social Deviance: Social Policy, Action and Research. London: Tavistock.

Wilson, R. J., Huculak, B. and McWhinnie, A. (2002), 'Restorative Justice Innovations in Canada', Behavioural Sciences and the Law, 20: 363-80.

Winick, B. (1998), 'Sex Offender Law in the 1990s: A Therapeutic Analysis', Psychology, Public Policy and Law, 4: 505-70.

Wright, M. (2002), 'The Court as Last Resort', British Journal of Criminology, 42: 654-67. 
Zedner, L. (1994), 'Reparation and Retribution: Are They Reconcilable?', Modern Law Review, 57: 228-50.

Zehr, H. (1990), Changing Lenses: A New Focus for Crime and Justice. Scottdale, PA: Herald Press.

(1995), 'Justice Paradigm Shift? Values and Vision in the Reform Process', Mediation Quarterly, 12: 207-16.

Zehr, H. and Mika, H. (1998), 'Fundamental Concepts of Restorative Justice', Contemporary Justice Review, 1: 47-55.

Zhang, S. X. (1995), 'Measuring Shame in an Ethnic Context', British Journal of Criminology, 35: 248-62. 